\title{
Review
}

\section{Self-realization and justice: A liberal-perfectionist defense of the right to freedom from employment}

\author{
Julia Maskivker \\ Routledge, New York, 2012, xiv+155pp., \$140.00/£85.00, ISBN: 978-0415889186
}

Contemporary Political Theory (2016) 15, e1-e3. doi:10.1057/cpt.2014.54

This interesting book explores and attempts to resolve a deep tension between two independently attractive liberal egalitarian commitments. The first is the familiar idea that in a just society people's important needs must be met - including needs for 'higher-order' goods like 'self-realization', understood as the development and exercise of talents, skills and abilities (p. 2). The second is the (perhaps less familiar) idea that people normally have a reciprocity-based duty not to free-ride on the efforts of others: they have a duty, that is, to make a personal productive contribution to society in return for benefits received.

Now, these two commitments do not always and everywhere conflict; we can perfectly well imagine social worlds in which people are able to discharge their contributive duties without frustrating any of their important needs. Take communism (as envisioned by Marx). In communist society, each is expected to contribute to the best of her abilities. But because 'society regulates the general production', it can arrange the division of labor (or, better, transcend this division) so that individuals are not confined to narrow, degraded, deskilled productive roles that threaten producers' interests in self-realization. Rather, communist society 'makes it possible for me to do one thing today and another tomorrow, to hunt in the morning, fish in the afternoon, rear cattle in the evening, criticize after dinner, just as I have a mind ...' (Marx, 1845). Unrealistic, perhaps, but the present point is just that Marx's society is one in which individuals can discharge their duty to contribute without jeopardizing their important interests in self-realization. Indeed, it is one in which contribution not only coheres with self-realization, but is itself an important vehicle for selfrealization. (Labor has, after all, become 'life's prime want' (Marx, 1975)).

So contribution can cohere with self-realization, at least in some distant possible world. How about in the actual world? Here, things are much grimmer; here, contribution too often crowds out the central human interest in self-realization. This is because contribution, under capitalism, usually takes the form of paid labor, and paid labor frequently undermines rather than facilitates self-realization, 
or so Maskivker persuasively argues. Jobs are oriented toward profits, not worker self-realization. True, some people are fortunate to have jobs that exercise and develop their higher talents and abilities - most readers of this review, for instance. But such jobs are increasingly the exception rather than the rule. Think, for instance, of the barista who poured your coffee, or the laborers who assembled your laptop, or the janitor who cleaned your office, or the HR clerk who processed your latest travel reimbursement. For such workers the benefits of work are almost entirely pecuniary and instrumental. Their work provides little to no opportunity to develop or exercise higher skills and abilities. Indeed, as thinkers like Adam Smith and Marx hypothesized, and as social scientists have since confirmed, simple, repetitive, closely supervised labor actually stunts and degrades these abilities, leaving workers less able to seek self-realization away from work. The point is that for the vast majority of workers in modern economies, the duty to contribute clashes with the moral entitlement (grounded, as Maskivker argues, in justice) to have one's basic interests (in this case, one's basic interest in self-realization) protected.

But what is to be done? How can society be re-arranged so as to make contribution compatible with self-realization? Maskivker's main proposal is to implement a 'participation income' (PI), which is a 'universal income conditioned only on broad participation in society' (p. 42). That participation be defined broadly here is key. One can earn the PI in many different ways: not just by engaging in paid labor, but also by volunteering in one's community, taking care of children or the ill or the elderly, and so on.

From Maskivker's perspective, the PI has two chief attractions. First - provided it is funded at a high enough level (an issue about which Maskivker might have said more) - it relaxes the 'work constraint', thereby giving each person real freedom to seek self-realization outside the narrow confines of paid employment (p. 35). Second, because the PI is conditional on participation, it avoids the 'reciprocity' or 'free rider' objections that dog proposals for an unconditional basic income. Such objections simply do not apply to PI, which is explicitly framed so as to deny free riders a free lunch. Summing up, Maskivker endorses the PI because it seems uniquely able to honor both liberal commitments identified above: it reinforces the duty to contribute (no free lunch), but it enables people to discharge this duty without sacrificing their prospects for self-realization in the process.

Let me note a few possible objections to Maskivker's view. First, her solution to the problem of inadequate opportunity for self-realization (that is, a PI) might be both excessive and inadequate. It might be excessive because the PI will go to everyone (who participates), even those people who can and do find self-realization through paid labor. People like you and me will get the check. Isn't this overkill? But at the same time, a PI may fail to protect the self-realization interests of at least some people, namely, those who find that none of the approved modes of participation on offer in their communities fit with - that is, develop or exercise - their particular skills, abilities and capacities. This objection simply extends Maskivker's insightful 
critique of paid work to other forms of social contribution. Just as an individual may find that none of the available job options fits with his or her talents and abilities, so too may an individual find that none of the available participation options - broadly defined as they are - exercises and develops his or her specific talents or abilities. After all, not everyone will find self-realization through volunteering at the library, or child care, or community clean-ups, and so on. The worry is that Maskivker's society will treat such people unfairly by forcing them to sacrifice their self-realization in order to receive the necessities of life. Isn't this just the oppressive work constraint in different guise?

Finally, one wonders how much difference a PI, set at a feasible level, would actually make to people's occupational choices (and thus to their levels of selfrealization). Many people might simply pocket the PI while working in the same job at the same hours as before. These people will be richer, but not more self-actualized. More effective, perhaps, would be a mixed strategy of improving work, sharing undesirable work and shortening the working day. Of course, a PI might be added into this mix. But how effectively would it increase experienced levels of selfrealization as a stand-alone policy? There is room for doubt here.

In sum, Maskivker makes an important and plausible self-realization-based case for attenuating the link between paid employment and economic survival. Philosophers and political theorists in the analytic tradition, as well as economists and others interested in the moral dimensions of economic life, will benefit from engaging with her provocative, rigorously argued book.

\section{References}

Marx, K. (1845) The German ideology. Marxists Internet Archive, https://www.marxists.org/archive/ marx/works/1845/german-ideology/, accessed 14 September 2014.

Marx, K. (1975) Critique of the Gotha program. Marxists Internet Archive, https://www.marxists.org/ archive/marx/works/1875/gotha/ accessed 14 September 2014.

Samuel Arnold

Texas Christian University, Fort Worth, TX 76126, USA

s.arnold@tcu.edu 